\title{
Economics
}

The Open-Access, Open-Assessment E-Journal

Vol. 12, 2018-24 | April 25, 2018 | http://dx.doi.org/10.5018/economics-ejournal.ja.2018-24

\section{Bridging the digital divide in the G20: skills for the new age}

\author{
Krish Chetty, Urvashi Aneja, Vidisha Mishra, Nozibele Gcora, \\ and Jaya Josie
}

\begin{abstract}
The digital divide in general, and between women and men in particular, is a manifestation of exclusion, poverty and inequality, and is likely to continue because of the effects of unemployment, poorly functioning digital skilling programmes and socio-cultural norms in some economies, and further depriving women equal access to digital services. Digital skills provide the poor a catalyst to break out of the cycle of poverty and empower themselves. This paper proposes a three-pronged digital skills strategy that will be required for developing countries to break out of the digital divide trap: (1) Monitor the evolving set of digital skills required for employment, (2) incorporate a holistic digital skills development strategy into national education programmes, and (3) contextualize skilling programs within prevailing socio-cultural norms that will shape the uptake and impact of digital skilling programs.

(Published as Global Solutions Paper)
\end{abstract}

$\begin{array}{lllllllllllll}\text { JEL } & \text { C83 } & \text { J20 } & \text { J22 } & \text { J23 } & \text { J24 } & \text { F63 } & \text { F66 } & \text { F68 } & \text { I24 } & \text { I25 } & \text { O15 } & \text { O19 }\end{array}$

Keywords Digital skills; digital divide; digitalization; information literacy; computer literacy; media literacy; communication literacy; technology literacy; socio-cultural norms

\section{Authors}

Krish Chetty, Human Sciences Research Council, Pretoria, South Africa, kchetty@hsrc.ac.za

Urvashi Aneja, Observer Research Foundation, New Dehli, India

Vidisha Mishra, Observer Research Foundation, New Dehli, India Nozibele Gcora, Human Science Research Council, Pretoria, South Africa Jaya Josie, Human Science Research Council, Pretoria, South Africa

Supported by: Emerging Market Sustainability Dialogues (EMSD), Economic Policy Forum (EPF), Deutsche Gesellschaft für Internationale Zusammenarbeit (GIZ) GmbH

Citation Krish Chetty, Urvashi Aneja, Vidisha Mishra, Nozibele Gcora, and Jaya Josie (2018). Bridging the digital divide in the G20: skills for the new age. Economics: The Open-Access, OpenAssessment E-Journal, 12 (2018-24): 1-20. http:// dx.doi.org/10.5018/economics-ejournal.ja.2018-24

Received August 4, 2017 Published as Economics Discussion Paper September 27, 2017 Revised March 16, 2018 Accepted March 29, 2018 Published April 25, 2018

(c) Author(s) 2018. Licensed under the Creative Commons License - Attribution 4.0 International (CC BY 4.0) 


\section{Background}

The digital divide is a manifestation of global inequalities. Those with greater capabilities can afford opportunities to gain the necessary skills to better leverage state and private sponsored investments in digital infrastructure and training. Conversely, impoverished communities with limited capabilities have fewer opportunities to gain the skills needed to advance within the rapidly transforming digital economy. With only $40 \%$ of the global population online and participating within the digital economy, addressing the digital divide is a pressing global challenge, which was recognised by the G20 under the stewardship of Germany in 2017 by calling for a more inclusive digital economy. Considering the rapid pace of technological advancement and the consequent inequalities, addressing the digital divide should be particularly high-up on the G20 agenda as the top-three countries with the largest offline population - India, China, and Indonesia - are all G20 members (McCauley, 2017) (see Figure 1).

The link between digital access and socio-economic conditions is borne out by the South African example. In South Africa, 35\% of households saw no relevance in accessing the internet, due primarily to their socio-economic circumstances (Statistics South Africa, 2015). It has also been noted that learners from families with high incomes have a greater affinity for using digital tools as compared to learners from low/middle income families. For example, Achuonye and Ezekoka (2011) discuss computer anxiety or 'technophobia' that learners from poorer communities in Nigeria exhibit when working with digital tools, simply due to the novelty of the occurrence. Similarly, Anthony et al. (2000) argue that technophobia can be correlated against the user's depth of computer experience.

Providing infrastructure in communities most affected by the digital divide will not alone resolve the problem of poor digital skills or lead to an immediate adoption of such facilities. For example, it was found in Brazil, that despite providing more infrastructure, large parts of the population did not perceive a need for digital access (Marcus et al., 2015). On the contrary, studies show that digital training is the vital ingredient in harnessing the ICT infrastructure investments made by both the public and private sectors (Bowles, 2013).

Unless a concerted effort is made to educate the population about the benefits of digital technologies and how to operate such facilities, the current structure of the divided digital

Figure 1: Percentage of individuals using the internet

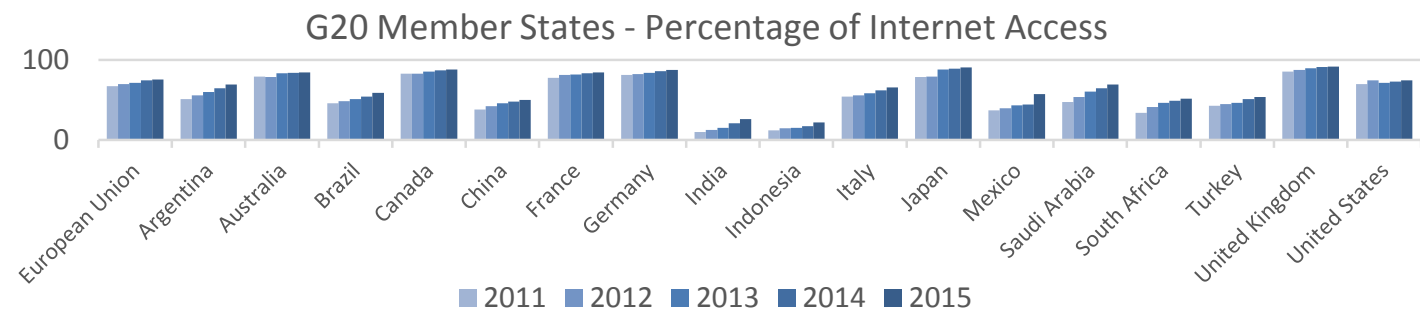

Source: International Telecommunication Union (2016) 
economy will exacerbate existing political and social inequities, particularly in low/middle income countries. An inclusive digital economy, that counters these divides, can lead to more trade, better capital use, improved efficiency, and accelerated innovation. To facilitate such benefits the G20 nations must take actions to address the challenges that maintain the digital divide.

In addition, socio-cultural factors strongly impede the access of digital tools by females. Johnson (2010) contends that in India for example, the low uptake of digital technologies by women is a result of prevailing roles, beliefs, and traditional norms. Son preferences within family units, community expectations, cultural norms that drive the sexual division of labour, such as a female's role in the household duties and chores, increases the perceived opportunity cost of sending a girl to school. In India, 23\% of girls drop out of school before they reach puberty. Consequently, these women are often not familiar with ICT and do not realize the value and empowering potential of ICTs (Gurumurthy and Chami, 2014). Other socio-cultural factors limiting women's access and use of ICTs include discriminatory attitudes against women's access to technology and technology education (Geertsema Sligh, 2006). For instance, a report by Intel (2013) titled 'Women and the Web' revealed that in 2012, one in five women in India thought internet usage to be inappropriate, non-beneficial and something that their families would disapprove of. In rural areas, negative questions that are often repeated are "What would a woman farmer want with a computer?". Further, $40 \%$ of women in this study expressed discomfort or a lack of familiarity as a reason for not using the internet. In terms of ICT ownership, rural women are less likely to own communication assets, such as a radio or mobile phone, compared to their male counterparts. This is because they are less likely to allocate their income to use in public communication facilities, except when they need to communicate with family or to arrange for income transfers (Deen-Swarray and Gillwald, 2012). The digital gender divide is thus, a combination of the lack of physical access, digital skills, opportunity and autonomy to make meaningful use of ICT, as these factors are strongly influenced by gender biased beliefs and value systems (Kularski and Moller, 2012).

The impact of ICTs in developing countries is also not gender neutral largely due to these entrenched socio-cultural norms and beliefs. In these cases, men tend to dominate access to employment, education and income sources and opportunities (Hilbert, 2011). However, as Hilbert suggests, an inclusive digital skills training programme must also provide opportunities for young girls to access the relevant basic skills valued by employers. However, without deliberate and focused programs for women and girls, the new digital economy will be exclusionary and reinforce existing gender and cultural disparities.

Considering the range of digitalization challenges affecting G20 countries, the strength of previous G20 recommendations to respond to these challenges has been weak in comparison. The issues of digitalisation and skills development have been raised consistently by the G20 but have not intersected prior to 2017. The G20 2015 Skills Strategy calls on G20 members to identify what skills are required by their respective labour markets, whilst not explicitly mentioning digital skills (G20 Leaders, 2015). In contrast, the digital skills agenda is far more advanced in some European countries. For example, Germany's Digital Agenda (2014-2017) provides a modern programme for training which includes professional development and the 
promotion of digital skills for all employees (German Federal Government, 2014). In addition, Europe's Digital Agenda details the need for effective, contextualized formal education, training and certification systems. This is to promote a more inclusive digital society involving technical, social, cultural, civic and creative skill-sets (Helsper and Deursen, 2015).

In short, the G20's position on Digital Skills lags behind the positions already adopted in developed nations. If the G20 was to adopt a stronger position on digital skilling, many low/middle income countries would benefit from such strategic guidance. Considering the expanding role that digitalization will play in the economy, the G20 must clarify its position on digital skills development and take actions to align the digital skills requirements of employers with those produced by education and training programmes.

\section{Objectives}

The G20 was formed in response to the Global Financial Crisis of 2008 to allow member nations to collaboratively counter the emergence of future crises. When considering that $60 \%$ of the global population are offline and effectively do not contribute the digital economy, the digital divide represents such a potential crisis. Action is needed to resolve the gulf in digital skills attainment between those with financial means and those without, however to date, policy priorities of the G20 pertaining to the digital divide have centred on optimising digital trade, financial inclusion and infrastructure development. Whilst, the G20 has recognized the importance of skills development, no connection was developed linking skills to the digital divide. It is the thesis of this study, that the lack of digital skills particularly amongst poor communities is a crucial determinant of digital exclusion. Whilst accepting that issues of infrastructure development and the cost of Internet connectively must be addressed, due attention must also be directed to upskilling the population.

To address the skills gap that exacerbates the digital divide it is necessary to recognise the multi-disciplinary nature of digital skills required in the modern digital economy. A holistic skills development programme across the G20 is required to align the needs of employers against the supply of skills from training programme. This study identifies the pertinent skillsets to be supported by digital training programmes within schools, vocational training facilities, universities and other training programmes across the G20. To do this, it will be important to standardize the skills outputs of training programmes across the G20, allowing citizens to receive training of comparable strength across G20 countries, in effect assisting to bridge the digital divide across G20 nations.

While it is vital for the G20 nations to devise a holistic skills development programme, this must include a conscious acknowledgement of country-specific social and cultural norms which will shape the uptake of skilling initiatives. In some countries, such norms have the effect of limiting women's opportunities to access training programmes and can exacerbate the digital divide if they are not adjusted to take account of the specificities of the limits to access to skills by women. Keeping in mind the heterogeneity across emerging and developing economies it is important to recognize these norms and to identify how the G20 can cooperate in forming and 
executing common policies, as well as context-specific pathways to reduce digital exclusionary practices.

\section{Approach}

The approach followed in this study involves a systematic review of international studies which describe the set of digital skills valued by employers. This involved performing a keyword and title search for journal articles across academic databases, using the keywords "digital literacy" and "definition" during 2005 to 2016. The results that emerged are listed in Table 1.

Although the topic of Digital Literacy alone is popular and commonly researched, the articles dedicated to its definition are limited. On further inspection of the abstracts of these 64 articles, it was found that very few of these studies were appropriately framed or instead, the context of the article narrowly defined a component of digital literacy. Due to this challenge, additional literature was reviewed. The second stage of the literature review involved a review of papers released by leading International organisations between 2010 and 2016 pertaining to Skills Development and to follow the references raised by the authors of these identified studies. The organisations identified include UNESCO, OECD, WEF and the Chinese Internet Network Information Centre (CINIC). From this combination of approaches, the key studies that were identified were produced by OECD (2016), SCONUL Working Group on Information Literacy

Table 1 - Results of keyword and title search across academic databases

\begin{tabular}{l|r}
\hline Database & Article Count \\
\hline OneFile (GALE) & 18 \\
\hline ABI/INFORM Complete & 8 \\
ABI/INFORM Global & 7 \\
\hline Taylor and Francis Online - Journals & 4 \\
ERIC (U.S. Dept. of Education) & 4 \\
\hline SAGE Journals & 4 \\
Agricultural and Environmental Science Database & 3 \\
\hline SpringerLink & 3 \\
ABI/INFORM Dateline & 1 \\
\hline JSTOR Current Journals & 3 \\
Directory of Open Access Journals (DOAJ) & 2 \\
Emerald Insight & 1 \\
\hline Literature Resource Center (Gale) & 1 \\
\hline Medline/Pubmed (NLM) & 2 \\
ScienceDirect Journals (Elsevier) & 2 \\
\hline Oxford Journals (Oxford University Press) & 1 \\
\hline
\end{tabular}


(2011), McKinsey and Company (2014), Pirzada and Khan (2013), Ridsdale et al. (2015), UNESCO (2011), Martin (2008), Covello (2010) and Bawden (2008).

This study synthesizes the emerging commonalities for determining the broad set of digital skill's disciplines. These skill-sets are associated with the type of employment opportunities available, and that were accessible when the associated level of skill is attained. In addition, relevant case studies were reviewed that discuss international best practices to developing an international skills training programme. Case studies from India and South Africa are reviewed to assess the role of socio-cultural norms with a focus on those that impede women from using digital technologies. The results of this review are presented in the section pertaining to the gender divide and socio-cultural norms. The Indian studies predominantly highlight sociocultural issues, whilst South African studies pertained to issues of the curriculum.

Furthermore, the qualification frameworks of India, South Africa and Europe were reviewed together with a collection of studies which described the concerns which described the challenges of embedding technology within the curricula. These points were included, as they are relevant in the manner G20 countries attempt to align their curricula to effectively respond to the changing digital skill demands of employers.

In addition, a quantitative assessment was conducted of all new jobs advertised on South Africa's premier recruitment website, www.CareerJunction.co.za. All relevant information describing the type of skills associated with the job advertisement, such as location, position, rank, salary and sector were extracted from the largely unstructured dataset. The information included in this analysis allows the determination of the toolsets and skill-sets required by employers in South Africa as of 18 May 2017 (the date of extraction). To identify the predominant skills which emerged on this day, text analysis was performed and sets of synonyms were grouped. For example, words such as Web or Internet were combined as the keyword frequencies were quantified. As job adverts can be categorised in terms of the sector or salary expectation (where provided), the jobs that were linked to digital skills were thereafter presented in terms of sector and annual salary. In future, this approach can be applied to other recruitment portals across the G20 to compare skill-set requirement differences amongst employers. The approach and analysis offer the G20 nations a practical solution to quantify the skills and tools needed and can be adopted by an international standard setting body to determine which skills are needed as technology progresses over time.

\section{$4 \quad$ Findings}

\subsection{The multidisciplinary nature of digital skills needed in the new age}

It is widely accepted that there are multiple forms of digital skills required by employers. It is therefore necessary not to adopt a narrow conceptual view of digital skills but to rather describe the five key disciplines of digital skilling, viz., the Information, Computer, Media, Communication and Technology literacies which emerge from the literature surveyed in this study as discussed by the OECD (2016), Pirzada and Khan (2013), the UNESCO Institute for 
Information Technologies in Education (2011), Martin (2008), Covello (2010) and Bawden (2008), amongst others.

In short, the key disciplines which emerge are mentioned in Table 2. Furthermore, by acquiring generic skills within these disciplines, one has a better chance to gain access to entry level employment opportunities. It is important to recognise that digital skills are multidisciplinary in nature and these skillsets will evolve over time, as employers' needs change.

Table 2: Synthesis of digital skill disciplines

\begin{tabular}{|c|c|}
\hline Discipline & Description \\
\hline Information & $\begin{array}{l}\text { - Finding, evaluating, organising and using digital content. } \\
\text { - Understanding the need for information and identifying what type of information } \\
\text { is needed } \\
\text { - Synthesising, creating new information }\end{array}$ \\
\hline Computer & $\begin{array}{l}\text { - } \quad \text { Competence in using hardware and software tools. } \\
\text { - } \quad \text { Ability to publish and communicate using available tools. } \\
\text { - } \quad \text { Using spreadsheets and word-processors. } \\
\text { - } \quad \text { Ability to tools for research and scholarship. } \\
\text { - }\end{array}$ \\
\hline Media & $\begin{array}{l}\text { - } \quad \text { Access, navigate, combine and edit text, sound, image and video media. } \\
\text { - } \quad \text { Integrating and comprehending sensory experiences. } \\
\text { - } \quad \text { The nature of web authorshiph } \\
\text { - Critical analysis, evaluation and production of mass media content. }\end{array}$ \\
\hline Communication & $\begin{array}{l}\text { - Using and constructing hyperlinks between documents and/or images, sounds, } \\
\text { movies, semiotic languages used in email, online chat space or in instant } \\
\text { messaging. } \\
\text { - Produce and critically evaluate 'non-linear' texts and navigating three- } \\
\text { dimensional worlds online. } \\
\text { - Communicating via multi-media platforms }\end{array}$ \\
\hline Technology & $\begin{array}{l}\text { - Ability to use technology within life situations. } \\
\text { - Ability to adopt, adapt, invent, and evaluate technology to improve their } \\
\text { livelihood and that of their community, and environment. }\end{array}$ \\
\hline
\end{tabular}

\subsection{Progressing from digital literacy to digital mastery}

There are three tiers to digital skills, viz., literacy, fluency, and mastery. The digitally literate can conduct basic functions using a range of technical tools. The digitally fluent user is more digitally capable than the digitally literate user as the user can analyse and process multiple streams of information and operate at a more proficient level. The attainment of a level digital mastery is possible when fully utilizing the various digital tools at one's disposal, and being able to produce new digital content (Ridsdale et al., 2015).

This three-tiered approach emphasised by the OECD (2016) identifies ICT generic skills attained at the level of becoming digitally literate, and ICT specialist skills which are attained at 
the levels of fluency and mastery. The OECD further identifies ICT complementary skills that are gained if learners can apply their skills in different work contexts. This type of skill usually manifests amongst employees that are at the fluent or master level. Skills complementarity is an important concept and arises from the multidisciplinary nature of digital skills. For example, a proficient programmer who understands digital media, could apply his programming knowledge innovatively in a new field.

It is crucial for low/middle income economies to ensure that disadvantaged communities receive the basic training needed to reach a state of digital literacy, however, once a state of literacy is attained, further training opportunities are needed to progress to levels of fluency and mastery. The most valued employees are those that can integrate digital tools seamlessly into their daily operational tasks. Thus, any digital skilling strategy must consider the longer-term requirements for mastery and the ability to apply such skills in other fields as well.

At a minimum, entry level jobs, needed in the modern economy require a broad set of generic skills, generally routine and manual in nature, related to information and computer skillsets. Depending on the sophistication of the task, intermediate or expert level jobs often require the employee possesses ICT specialist skills which, for example, allows the employee to programme, develop applications and manage networks. Jobs requiring problem solving abilities are not generally associated with entry level positions.

Importantly, the core skills needed, particularly in developing countries are the generic entry level skills linked to the information and computer skill-sets. These skills are considered gateway skills, enabling the learner to better grasp entry level concepts in other subject areas such as Media, Communication and Technology. The attainment of such digital skills, in addition to completing secondary schooling in South Africa, provides the learner the critical labour market access in the form of semi-skilled work opportunities, which breaks the cycle of poverty besetting poorer communities (Spaull, 2015). This stepping stone out of poverty can provide the learner further access to vocational training or universities. The absence of such skills denies the learner this vital initial access to formal employment.

\subsection{A snapshot of South Africa's digital skills needs}

An analysis of junior positions in South Africa posted on www.CareerJunction.co.za allows the identification of the predominant skills required by employers. By applying the identified skills framework, it is possible to categorize the skill requirements of employers. Of the positions identified, it can be noted that the technology discipline dominates new junior level positions across sectors, followed by careers requiring information and computer related skills (Table 3).

With respect to the information skills that are needed, tasks that require data manipulation were predominant, followed by the ability to find information on the Internet via database querying and an understanding of search engines. Junior positions that required data analysis and usage are commonly found in the Administration, Business Management, Finance, IT, Medical and Sales sectors (Table 4). 
Table 3 - Most common skills required per discipline amongst junior positions in South Africa

\begin{tabular}{|c|c|c|c|c|c|c|c|c|c|}
\hline \multicolumn{2}{|l|}{ Information } & \multicolumn{2}{|l|}{ Computer } & \multicolumn{2}{|l|}{ Media } & \multicolumn{2}{|l|}{ Communication } & \multicolumn{2}{|l|}{ Technology } \\
\hline $\begin{array}{l}\text { Database } \\
\text { usage }\end{array}$ & 25 & Sage & 71 & $\begin{array}{l}\text { Media } \\
\text { knowledge }\end{array}$ & $\begin{array}{l}1 \\
3\end{array}$ & Telecoms & 20 & $\begin{array}{l}\text { Business } \\
\text { Intelligence }\end{array}$ & 82 \\
\hline Querying & 22 & ERP & 34 & Photoshop & $\begin{array}{l}1 \\
1\end{array}$ & SMS & 5 & Java & 73 \\
\hline Research & 17 & $\begin{array}{l}\text { Computer } \\
\text { Literate }\end{array}$ & 31 & Visual aids & 7 & Skype & 4 & Web Development & 43 \\
\hline Web usage & 9 & MS Office & 23 & TV & 2 & ISO policies & 3 & Cabling & 35 \\
\hline Web Skills & 8 & Syspro & 20 & Sound & 1 & Twitter & 2 & HTML & 33 \\
\hline Forecasting & 8 & Server skills & 19 & 4d illustrator & 1 & Messaging & 2 & .NET Development & 31 \\
\hline \multirow[t]{2}{*}{ Searching } & 8 & SAP & 17 & Radio & 2 & VOIP & 1 & UI & 22 \\
\hline & & & & & & & & Tech savvy & 22 \\
\hline
\end{tabular}

Table 4 - Junior positions that require technology skills per annual income band and sector

\begin{tabular}{|c|c|c|c|c|c|}
\hline & 0-R54,000 & $\begin{array}{l}\text { R54,000- } \\
\text { R120,000 }\end{array}$ & $\begin{array}{l}\text { R120,000- } \\
\text { R252,000 }\end{array}$ & $\begin{array}{l}\text { R252,000- } \\
\text { R684,000 }\end{array}$ & $>$ R684,000 \\
\hline Sales & 25 & 17 & 4 & & \\
\hline Finance & 4 & 13 & 14 & 14 & 1 \\
\hline Information Technology & 3 & 6 & 18 & 17 & \\
\hline Admin, Office and Support & 10 & 10 & 1 & & \\
\hline Business and Management & 3 & 4 & 2 & 6 & 1 \\
\hline Marketing & 4 & 5 & 1 & & \\
\hline Cleaning and Maintenance & 4 & 4 & 2 & & \\
\hline Warehousing & & 5 & 1 & 1 & \\
\hline Design and Media & 1 & 3 & 2 & & \\
\hline Building and Construction & & 2 & 1 & & \\
\hline Restaurant and Hospitality & 1 & 1 & & & \\
\hline Manufacturing and assembly & & & & 1 & \\
\hline
\end{tabular}

In terms of computer skills, the knowledge and ability to effectively work with Microsoft Office, particularly Excel, featured strongly. In this discipline, it was also found that knowing how to operate an Enterprise Resource Planning (ERP) system was particularly useful to employers. The Sage and SAP systems were often requested amongst junior positions. This is notable, as school, tertiary and vocational training programmes in South Africa do not offer 
training to operate an ERP system. Current training pertaining to ERP systems is limited as a part of an Information System's course, with a greater emphasis on the design of such systems and not its operation. Operational skills are however gained via on-the-job experience.

Media related skills were the least frequent set of skills required by employers in South Africa. In this discipline, it was noted that graphic design skills featured within the architecture and design type job advertisements. The majority of these positions are offered as permanent positions in the Finance, Design and Media, Marketing and Sales sectors. Such positions generally require the incumbent to concentrate on branding related activities.

Communications skills were also found to cut across sectors. The most prevalent requirement was the ability to write reports. Thus, the applicant needs to be capable in using a word processor. The expectation amongst these positions, is that the applicant is well-versed in using the software and often using a tool such as Microsoft Word is not explicitly mentioned in the job advertisement. In addition to having strong writing skills, using new forms of technology to communicate was noted, with some positions requiring the applicants to be able to use Skype, social media in general, Twitter specifically, to be able to send messages as well understanding how to communicate using VOIP based tools.

Technology related skills were the most commonly requested skills from employers at the junior level. Database management skills are commonly required which is associated with using SQL for database querying and various other programming languages. It is also important for the applicant to understand the development principles for these types of jobs. Jobs with an annual income band of R54,000 to R120,000 were most common at the junior level. Interestingly, jobs where the applicant would earn up to R120,000 were found in sectors such as Sales (Retail), Finance and Administration and highlights that these skills can act as a gateway to productive employment in traditionally non-IT related sectors.

\subsection{The need for a holistic skills development strategy}

The challenge faced by all policy makers is to determine how to ensure policy making pertaining to digital skills development is as responsive as the rapid pace of change in the international labour market. Employer requirements for new skills constantly change as the digital economy evolves. Consequently, any digital education minimum standards must be informed by a dynamic and responsive standard setting body. Such a body should serve as the link between employers, trainers, policy makers and academics (see Figure 2). The duties of such a body would include (1) monitoring and identifying the skills requirements of resources required by employers, (2) guiding digital education and training programmes on the content of their curricula and (3) ensuring that academics and policy makers have an opportunity to debate the future direction and content of digital skills training programmes.

The literature suggests that businesses are holding training institutions responsible for not producing sufficient graduates with suitable digital skills (Calitz, 2010; Calitz et al., 2014). This implies the need to align the demands of the employer with the curricula offered by secondary 
Figure 2: Contributors to a digital skills standard setting body

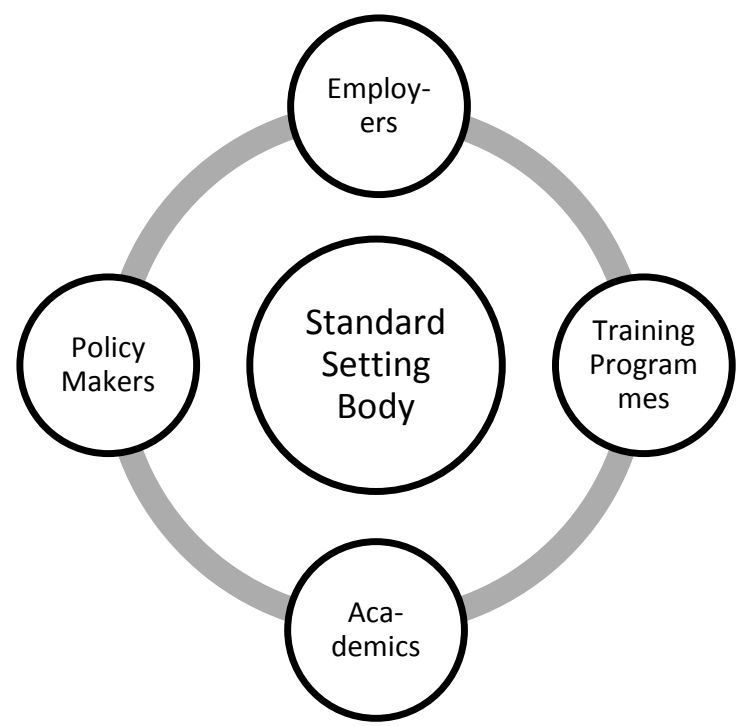

schools, vocational training facilities, digital training programmes and universities. Employers' needs will rapidly change, and the set of digital skills required today are likely to change in the future. Academics will play a vital role in guiding the standard setting body in the manner it adapts training programmes according to the evolving labour market. Policy makers, will require guidance and assistance in the manner they balance the demands of employers against the skills supplied by existing training programmes and the requisite needs of such programmes.

The OECD (2016) argues that when learners exit compulsory education they should be equipped with a proficient level of digital skills. In addition to identifying these skills, and what determines a suitable proficiency level, countries must also address the traditional challenges faced within the education sectors in low/middle income economies. These challenges include strengthening foundational skills such as literacy and numeracy, reducing school dropouts, targeting grade-repetition and promoting good teaching practices in schools. Further, in low/middle income economies, not all schools provide digital training to learners and such training, when available, may not be compulsory. In poorer communities, it is more commonly found that dropout rates are high, quality and infrastructure of schools are poor, and girls often do not receive sufficient schooling due to a combination of social and cultural norms (Spaull, 2015).

It is vital that G20 countries structure the school system and curriculum in a manner that is aligned with the needs of employers. In South Africa, the National Qualification Framework (NQF) structures the streams of education through ordinary schooling, adult education, vocational training and tertiary education. Compulsory education ends at Grade 9. Thereafter, a learner either continues within the ordinary school stream or accesses either adult education or vocational training. Thus, the alignment discussed by the OECD must determine what skills 
should be offered to a learner exiting the school system from Grade 9/NQF Level 1 to students that complete a PHD/NQF Level 10.

Whilst South Africa's NQF is aligned to international qualification frameworks such as the Bologna Process, the European Qualifications Framework and India's NQF (European Commission - Education and Training, n.d., NUFFIC Internationalising Education, 2015) (see Table 5), it is important to determine the required digital skill, knowledge and competence that must be attained at each level via each education stream. In addition, private training programmes, not affiliated to their respective countries national qualification framework, should endeavour to align the content of their training programmes against the identified digital skills needs of employers.

Often, there is a lack of alignment between the various education streams. For example, in South Africa, it was found that there is a disconnect between the entrance requirements of higher education programmes and the Computer Applications Technology (CAT) subject offered in secondary schools (Mdlongwa, 2012). CAT is offered in Grades 10, 11 and 12 and the subject trains learners in a basic set of multi-disciplinary ICT skills. However, the subject is not credited by universities and therefore does not incentivise learners to enroll. The subject provides valuable training in areas such as software development, hardware maintenance and networking, however many poorer schools are ill-equipped to provide such training. Thus the holistic skills development strategy must cater for unaffordable requirements such as providing infrastructure, trained instructors, software, a maintenance plan, and insurance to combat effects of theft (South African Department of Basic Education, 2010).

Table 5 - Alignment between the South African NQf, Indian and European Qualification Framework

\begin{tabular}{|c|c|c|c|c|c|c|c|c|c|c|}
\hline $\begin{array}{l}\text { SA NQF } \\
\text { Level }\end{array}$ & NQF1 & NQF2 & NQF3 & NQF4 & NQF5 & NQF6 & NQF7 & NQF8 & NQF9 & NQF10 \\
\hline $\begin{array}{l}\text { European } \\
\text { EQF Level }\end{array}$ & \multicolumn{2}{|l|}{ EQF1 } & EQF 2 & EQF3 & EQF 4 & EQF 5 & EQF 6 & EQF 6 & EQF 7 & EQF 8 \\
\hline India NQF & NQF1 & NQF2 & NQF3 & NQF4 & NQF5 & NQF6 & NQF7 & NQF8 & NQF9 & NQF10 \\
\hline $\begin{array}{l}\text { SA } \\
\text { Ordinary } \\
\text { School }\end{array}$ & $\begin{array}{l}\text { Grade } \\
9\end{array}$ & Grade 10 & Grade 11 & Grade 12 & $\begin{array}{l}\text { Higher } \\
\text { Certificate } \\
-1^{\text {st }} \text { Year }\end{array}$ & $\begin{array}{l}\text { Diploma/ } \\
2^{\text {nd }} \text { Year }\end{array}$ & $\begin{array}{l}\text { Degree/ } \\
3^{\text {rd }} \text { Year }\end{array}$ & Honours & Masters & PHD \\
\hline \multirow{2}{*}{$\begin{array}{l}\text { SA } \\
\text { Vocational } \\
\text { Training }\end{array}$} & & NATED 1 & NATED 2 & NATED 3 & \multirow[t]{2}{*}{ N4-N6 } & \multirow{2}{*}{$\begin{array}{l}\text { Internship/ } \\
\text { Diploma }\end{array}$} & & & & \\
\hline & & $\begin{array}{l}\text { National } \\
\text { Certificate } \\
\text { Vocational } \\
\text { - 1st year }\end{array}$ & $\begin{array}{l}\text { National } \\
\text { Certificate } \\
\text { Vocational } \\
\text { - 2nd year }\end{array}$ & $\begin{array}{l}\text { National } \\
\text { Certificate } \\
\text { Vocational } \\
\text { - 3rd year }\end{array}$ & & & & & & \\
\hline $\begin{array}{l}\text { SA Adult } \\
\text { Education }\end{array}$ & & NQF2 & NQF3 & NQF4 & NQF5 & NQF6 & & & & \\
\hline
\end{tabular}


Furthermore, the education programme in general needs to embed digitalisation across the curricula. The concerns of technophobia emanate from an unfamiliarity associated with digital technologies and services. Embedding and integrating digital tools into teaching practices in earlier schooling phases will assist to overcome this unfamiliarity. A new practice-ready education paradigm is recommended to keep the education system responsive and agile to the ever changing emerging technologies (Calitz, 2010; Noel and Liub, 2017; Aflatoony and Wakkary; 2015).

\subsection{Responding to the gender divide and socio-cultural norms}

While the digital divide exists in varying degrees across the G20, poorer communities and rural women in the developing world tend to be the least digitally included. For instance, only about 29 percent of internet users and 28 percent of mobile phone owners are women (Aneja and Mishra, 2017). In addition to the high cost of access to new technologies combined with the low level of female purchasing power, infrastructural constraints (the determining aspects of gendered digital exclusion in developing countries), are the impact of gender-biased belief and value systems that impose restrictions on the education and free mobility of women, indirectly exacerbating the digital skills divide (Mishra, 2017).

For instance, most ICT training centres are run from public spaces. Rural women are often reluctant or not allowed to visit "cyber cafes," public internet centres, or community training centres that are often owned by men or visited predominantly by men. Further, training programmes often fail to take women's 'time poverty' into account (Desai, 2016). Time poverty is defined as scarcity of time rural women face because of their multiple roles and heavy domestic responsibilities that limit the time they can allocate to learning and using ICTs. When training programmes run during early morning, or late evening hours, they limit women's participation in training and education. There will be a greater chance for success if these factors are considered when designing digital training programmes.

In addition, Google, in association with TATA Trusts India, launched the 'Internet Saathi' campaign in July 2015 to bring 5 million women from villages online over a period of 18 months by teaching them how to use tablets and smartphones (Google India, 2015). While the exact number of women trained in sustained and productive usage of the Internet is unavailable, the programme was successful in familiarising and making the rural population comfortable with hardware and the Internet. What set the Internet-Saathi model apart was the fact that it only used local women as trainers. Having local women trainers ensured continuity in the process of learning and imparting hands-on training to women and children in villages. This approach made it a highly scalable and sustainable programme.

When designing digital training programmes, simply making these programmes accessible to women is unlikely to yield the desired results. The programmes must be context and needspecific. For instance, investing in efforts to minimise the gender gap in science and technology education through such 'ICTs in public schooling' initiatives can be beneficial in urban contexts. At the same time, considering that a significant number of girls drop out of formal schooling 
post puberty (Gurumurthy and Chami, 2014), it is important to explore the potential of ICTs for educating out-of-school adolescent girls and supporting the learning-action processes of adult women who may not be textually literate.

Today, new technology can also be a skill-provider. When such tools are made available to women, it can reduce the gaps created through the formal education system. For instance, Barefoot College, a school in the North Western state of Rajasthan, India, provides professional training for rural women to use cell phones through innovative techniques where formal education or reading skills are not a prerequisite (Barefoot College, 2015). In this way, even illiterate, older local women entrepreneurs can use it in the marketplace.

In addition to generic digital skills training, there is a need to offer digital skills training programmes that highlight how women entrepreneurs can use and benefit from e-commerce services. E-commerce offers women the opportunity and flexibility to work from home. It eases not only the selling of products and services online but can also promote the productivity and competitiveness of women entrepreneurs in rural and urban areas. This is done by linking producers and traders directly to markets at national, regional and even global levels, allowing them to restructure their economic activities and bypass intermediaries and the male-dominated and exploitative market structure (UNCTAD, 2002).

For instance, the Self-Employed Women's Association (SEWA) Trade Facilitation Centre (STFC) in India showcases members' products online, facilitates business-to-consumer sales, and builds business-to-business links through the use of ICTs and E-commerce (Self Employed Women's Association, 2014). However, the extent to which women can control the transactions is unclear, making SEWA an intermediary as well. This necessitates research into what digital software applications and training capacities are needed to ensure that urban and rural women etraders retain their agency, and avoid the same obstacles present in the economy in general.

However, it is also important to note that the gender dimension of digital exclusion can have varying manifestations. For instance, even in the US, where age, ethnicity and location are bigger determinants than gender in terms of digital access and usage, women's underrepresentation in fields of science, technology, engineering, and mathematics (STEM) fields is a growing concern: only 18 percent of women earned a bachelor's degree in engineering in 2012. STEM jobs are estimated to grow faster than any other sector in the future, and it has been estimated that as many as 40 million jobs could go unfilled due to the emerging skills-gap (Dobbs et al., 2012). In addition to widening the existing deficit of women in highskill technical jobs and research, the deficit of women in STEM fields is leading to new technologies being developed almost exclusively by men. Consequently, in-built sexism in artificial intelligence and robotics is already visible. If the present situation persists, it is likely to exacerbate existing inequalities in work opportunities and outcomes. Therefore, the focus needs to be on not only increasing women's digital literacy, but also their digital mastery (Mishra, 2017).

It is important to distinguish digital skills from understanding the value of digital/ICT skills. If we are to institute a holistic skills upliftment strategy, it is important to recognise the sociocultural context of communities which may undermine the delivery of digital training courses. The perceived lack of value of digital tools and advancements in some communities emerges 
from their lack of knowledge of the pace of technological change and its impact on society at the macroeconomic level. Countering these misconceptions by educating the misinformed is therefore a valuable pursuit, to ensure new digital training programmes are effectively instituted. Thus, the training programmes which are delivered must be mindful of such dynamics and be designed in manner to counter such responses.

\section{$5 \quad$ Recommendations}

\subsection{G20 to monitor the digital skills required for employment}

It is essential for the G20 nations to institute a process to identify and track the digital skills required by employers internationally. The G20 must recognise that the skills required by employers are multidisciplinary and pertain to the Information, Computer, Media, Communication and Technology literacies. It is the specific tools used in these spaces that rapidly evolve due improved efficiencies and innovative practices. In response, the G20 must introduce innovative mechanisms to follow the shifting trends in technologies required in the labour market to become more agile in the manner education programmes are structured. Monitoring the skills required should be conducted internationally and locally. This approach will allow countries to compare their current requirement against the international norms across sectors. Producing such insights will be beneficial to employers to benchmark their business practices and keep pace with the evolving international norm.

\subsection{G20 to develop and guide a holistic digital skills upliftment strategy}

In addition to monitoring skills required in the labour market across sectors, it is important to introduce responsive processes which allow nations to collectively monitor and organise their respective education programmes to incorporate the new training requirements of employers. Setting up a broad G20 standard setting body will allow employers, trainers, academics and policy makers the opportunity to debate the future direction of the digital education curricula. This body will assist national qualification frameworks to find a common set of standards that apply across nations, allowing member countries to produce similarly skilled graduates, regardless of their location of study. Thus, providing poorer learners greater opportunities to access the labour market and breakout of poverty.

\subsection{G20 nations to address the social and cultural norms}

Advocacy and awareness generation programmes are necessary to challenge entrenched social attitudes and at the same time, concrete policy solutions need to be identified to improve women's socio-economic status. For this, the G20 must address the severe lack of funding to 
tackle pervasive social inequities. For instance, it was estimated that even though global aid is rising, aid to education has fallen $10 \%$ in 2009 to $6.9 \%$ by 2015 . Crucially, at present only two G20 donor countries are dedicating the recommended 15 percent of their total aid to education (Johnston and Royle, 2017).

Secondly, it is clear that most studies on women's empowerment and digital inclusion in the G20 context have remained anecdotal. There is a dearth of sex-disaggregated data on women's access and usage of ICT, as well as of qualitative studies on attitudes and stereotypes that shape unconscious bias. While the Digital Opportunity Index (DOI) was introduced in 2005 to track digital inclusion, it does not collect sex-disaggregated statistics. There is an opportunity to undertake empirical research to map out future policy pathways. Lastly, as the case studies demonstrate, it is important that the G20 refrains from broad based brush-stroke solutions to tackle gendered digital exclusion. 


\section{References}

Achuonye, K. A., and Ezekoka, G. K. (2011). Technophobia among Female Undergraduate Students : A Challenge to Attainment of the MDGs in Nigeria. British Journal of Educational Research, 1(1): 49-57. http://www.journalrepository.org/media/journals/BJER_17/2011/Sep/1315058311Achuonye_Ezekoka_2011BJER538.pdf

Aflatoony, L., and Wakkary, R. (2015). Thoughtful Thinkers: Secondary Schoolers' Learning about Design Thinking. Proceedings of 3rd International Conference for Design Education Researchers: LearnxDesign 2015, 10 pages. In press. http://summit.sfu.ca/item/15249

Aneja, U., and Mishra, V. (2017). Digital India Is No Country for Women. Here’s Why. The Wire. 25 May 2017. https://thewire.in/139810/digital-india-women-technology/

Anthony, L. M., Clarke, M. C., and Anderson, S. J. (2000). Technophobia and Personality Subtypes in a Sample of South African University Students. Computers in Human Behavior, 16(1): 31-44. http://doi.org/10.1016/S0747-5632(99)00050-3

Barefoot College (2015). The Barefoot Model for Global Sustainability 2015 UN Sustainable Goals. Retrieved from https://www.barefootcollege.org/wp-content/themes/barefoot-college/download/barefoot-whitepaper.pdf

Bawden, D. (2008). Origins and Concepts of Digital Literacy. In Colin Lankshear \& Michele Knobel, Editors (Eds.), Digital Literacies: Concepts, Policies and practices (1st Edit.). New York: Peter Lang Publishing Inc.

Bowles, M. (2013). Digital Literacy and e-skills: Participation in the Digital Economy, Australia, Melbourne, viewed 10 Apr 2018.

https://www.ibsa.org.au/sites/default/files/media/Digital\%20Literacy\%20and\%20E-skills.pdf

Calitz, A. P. (2010). A Model for the Alignment of ICT Education with Business ICT Skills Requirements. Nelson Mandela Metropolitan University. http://hdl.handle.net/10948/1418

Calitz, A. P., Greyling, J. H., and Cullen, M. D. M. (2014). South African Industry ICT Graduate Skills Requirements. Southern African Computer Lecturers' Association (SACLA), (1), 25-26. https://www.researchgate.net/publication/281292435_South_African_Industry_ICT_Graduate_Skill s_Requirements

Covello, S. (2010). A Review of Digital Literacy Assessment Instruments. Syracuse University. Retrieved from: http://www.academia.edu/7935447/A_Review_of_Digital_Literacy_Assessment_Instruments

Deen-Swarray, M.,Gillwald, A., Morell, A., and Khan, S. (2012). Lifting the Veil on ICT Gender Indicators in Africa. Evidence for ICT Policy Action, Policy Paper 13. Research ICT Africa \& University of Cape Town.

https://www.researchictafrica.net/publications/Evidence_for_ICT_Policy_Action/Policy_Paper_13_ -_Lifting_the_veil_on_gender_ICT_indicators_in_Africa.pdf

Desai, S. (2016). Declining Sex Ratios Seen in Gender Scorecard. Comment. The Hindu. Retrieved February 26, 2017, from http://www.thehindu.com/opinion/op-ed/declining-sex-ratios-seen-ingender-scorecard/article5801673.ece 
Dobbs, R., Madgavkar, A., Barton, D., Labaye, E., Manyika, J., Roxburgh, C., Lund, S., and Madhav, S. (2012). The World at Work: Jobs, Pay , and Skills for 3.5 Billion People. Report McKinsey Global Institute. June 2012. Retrieved from http://www.mckinsey.com/global-themes/employment-andgrowth/the-world-at-work

European Commission - Education and Training (n.d.). The Bologna Process and the European Higher Education Area. Retrieved May 15, 2017, from http://ec.europa.eu/education/policy/highereducation/bologna-process_en

G20 Leaders (2015). G20 Skills Strategy. Antalya, Turkey. Retrieved from http://g20.org.tr/wpcontent/uploads/2015/11/G20-Skills-Strategy.pdf

Geertsema Sligh, M. (2006). Gender and the Digital Economy : Perspectives from the Developing World. Asian Journal of Communication, 16(4): 440-442.

http://digitalcommons.butler.edu/cgi/viewcontent.cgi?article=1033andcontext=ccom_papers

German Federal Government (2014). Digital Agenda 2014-2017. Munich. https:/www.digitaleagenda.de/Content/DE/_Anlagen/2014/08/2014-08-20-digitale-agendaengl.pdf?_blob=publicationFileandv=6

Google India (2015). Digitising India - One Woman at a Time with “Internet Saathi.” Retrieved February 26, 2017, from https://india.googleblog.com/2015/07/digitising-india-one-women-at-time-with.html

Gurumurthy, A., and Chami, N. (2014). Digital Technologies and Gender Justice in India - An Analysis of Key Policy and Programming Concerns. Input to the High Level Committee on the Status of Women in India. IT for Change, April 2014. https:/www.itforchange.net/sites/default/files/IT for Change - HLPC Submission - 16 April 2014-1.pdf

Helsper, E., and Deursen, J.A. M. (2015). Digital Skills in Europe: Research and Policy. In Kim Andreasson (Ed.), Digital Divides. Edition: 1, Chapter: 7: 125-146. CRC Press. https://www.researchgate.net/publication/275350550_Digital_Skills_in_Europe_Research_and_Pol icy

Hilbert, M. (2011). Digital Gender Divide or Technologically Empowered Women in Developing Countries? A Typical Case of Lies, Damned Lies, and Statistics. Women's Studies International Forum, 34(6): 479-489. http://www.martinhilbert.net/DigitalGenderDivide.pdf

Intel (2013). Women and the Web.

Retrieved from https://www.intel.com/content/www/us/en/technology-in-education/women-in-theweb.html\#

International Telecommunication Union (2016). Facts and 2016 Figures. http://www.itu.int/en/ITUD/Statistics/Documents/facts/ICTFactsFigures2016.pdf

Johnson, V. (2010). Women and the Internet: A Micro Study in Chennai, India. Indian Journal of Gender Studies, 17(1): 151-163. http://doi.org/10.1177/097152150901700107

Johnston, B., and Royle, T. (2017). G20 Will Never Get Women to Work Without Investing in Girls’ Education. News Deeply - Women's Advancement Deeply, 21 June 2017. https:/www.newsdeeply.com/womenandgirls/community/2017/06/21/g20-will-never-get-womento-work-without-investing-in-girls-education

Kularski, C. M., and Moller, S. (2012). The Digital Divide as a Continuation of Traditional Systems of Inequality. 14 December 2012. Available at: http://papers.cmkularski.net/20121214-2699.pdf 
Marcus, A., Weinelt, B., and Goutrobe, A. (2015). Expanding Participation and Boosting Growth: The Infrastructure Needs of the Digital Economy. World Economics Forum. http://www3.weforum.org/docs/WEFUSA_DigitalInfrastructure_Report2015.pdf

Martin, A. (2008). Digital Literacy and the “Digital Society.” In C. Lankshear (Ed.), Digital Literacies: Concepts, policies and practices (1st Edit.). New York: Peter Lang Publishing Inc.

McCauley, D. (2017). The Inclusive Internet Index: Bridging digital divides. (P. Swabey, Ed.). Retrieved from https://theinclusiveinternet.eiu.com/assets/external/downloads/3i-bridging-digital-divides.pdf

Mdlongwa, T. (2012). Information and Communication Technology ( ICT ) as a Means of Enhancing Education in Schools in South Africa : Challenges, Benefits and Recommendations. AISA Policy Brief, (80): 1-8. Retrieved from http://www.ai.org.za/wp-content/uploads/downloads/2012/10/No.80.-ICTas-a-means-of-enhancing-Education-in-Schools-in-South-Africa.pdf

Mishra, V. (2017). Empowering Women in the Digital Age. Commentaries, ORF Oberserver Research Foundation. Retrieved from http://www.orfonline.org/research/empowering-women-digital-age/

Noel, L.-A., and Liub, T. L. (2017). Using Design Thinking to Create a New Education Paradigm for Elementary Level Children for Higher Student Engagement and Success. Design and Technology Education: An International Journal, 22(1). https://ojs.lboro.ac.uk/DATE/article/view/2198

NUFFIC Internationalising Education (2015). The Indian Education System Described and Compared with the Dutch System. Education system India | EP-Nuffic | 2nd edition January 2011 | version 2, January 2015. https://www.nuffic.nl/en/publications/find-a-publication/education-system-india.pdf

OECD (Organisation for Economic Cooperation and Development) (2016). Working Party on Measurement and Analysis of the Digital Economy. Skills for a Digital World. Paris : OECD Publishing. http://pmb.cereq.fr/doc_num.php?explnum_id=3105

Pirzada, K., and Khan, F. N. (2013). Measuring Relationship between Digital Skills and Employability. European Journal of Business and Management, 5(24): 124-133. Retrieved from http://pbdd.org/wp-content/uploads/2016/07/Measuring_Relationship_between_Digital_Skills-andemployability.pdf

Ridsdale, C., Rothwell, J., Smit, M., Ali-Hassan, H., Bliemel, M., Irvine, D., Kelley, D., Matwin, S., and Wuetherick, B. (2015). Strategies and Best Practices for Data Literacy Education: Knowledge Synthesis Report. Dalhousie University. http://www.mikesmit.com/wp-content/papercitedata/pdf/data_literacy.pdf

Self Employed Women's Association (2014). Self Employed Women's Association Background. Retrieved from https://cdn.questromworld.bu.edu/studyabroad/files/2014/04/SEWABackground.pdf

South African Department of Basic Education (2010). National Curriculum Statement (NCS), Curriculum and Assesment Policy Statement, Computer Applications Technology.

https:/www.education.gov.za/Portals/0/CD/National\%20Curriculum\%20Statements\%20and\%20V ocational/CAPS\%20FET\%20_\%20COMPUTER\%20APPLICATIONS\%20TECHNOLOGY\%20_ \%20GR\%2010-12\%20_\%20Web_6AC6.pdf?ver=2015-01-27-154348-193 
Spaull, N. (2015). Schooling in South Africa: How Low Quality Education Becomes a Poverty Trap. South African Child Gauge, (12), 34-41. http://nicspaull.com/research/

Statistics South Africa (2015). General Household Survey 2015. Retrieved from www.statssa.gov.za

UNCTAD (2002). E-commerce and Development Report 2002. United Nations, Geneva.

http://unctad.org/en/Docs/ecdr2002_en.pdf

UNESCO Institute for Information Technologies in Education (2011). Digital Literacy in Education. Policy Brief, May 2011. http://unesdoc.unesco.org/images/0021/002144/214485e.pdf 


\section{Economics}

Please note:

You are most sincerely encouraged to participate in the open assessment of this article. You can do so by either recommending the article or by posting your comments.

Please go to:

http://dx.doi.org/10.5018/economics-ejournal.ja.2018-24

The Editor 